\title{
PENERAPAN MODEL PEMBELAJARAN KOOPERATIF TIPE “STAD” BERBANTUAN MEDIA TEKA-TEKI SILANG UNTUK MENINGKATKAN PENGUASAAN HURUF HIRAGANA SISWA KELAS XI BAHASA SMA NEGERI 1 KUTA SELATAN TAHUN AJARAN 2017/2018
}

\author{
Dewi, N. P. T. T 1 , Suartini, N.N² , dan Hermawan, G. S $^{3}$ \\ 123 Jurusan Pendidikan Bahasa Jepang, Universitas Pendidikan Ganesha, Singaraja,Bali \\ e-mail: dewi.putu28@undiksha.ac.id, nnsuartini@undiksha.ac.id, satya.hermawan@undiksha.ac.id,
}

\begin{abstract}
Abstrak
Penelitian ini bertujuan untuk meningkatkan penguasaan huruf Hiragana dan respons siswa terhadap penerapan model pembelajaran kooperatif tipe STAD berbantuan media teka-teki silang. Jenis penelitian ini adalah penelitian tindakan kelas (PTK) dengan dua siklus. Subjek penelitian ini adalah 28 siswa kelas XI Bahasa SMA Negeri 1 Kuta Selatan. Metode pengumpulan data yang digunakan adalah observasi, tes, dan kuesioner. Data yang telah dikumpul dianalisis secara deskriptif kualitatif. Penelitian ini menunjukkan bahwa penerapan model pembelajaran kooperatif tipe STAD berbantuan media teka-teki silang mampu meningkatkan penguasaan huruf Hiragana siswa yaitu, pre-test dengan rata-rata 50,53 dan ketuntasan klasikal $17,85 \%$. Siklus I rata-rata 78 dan ketuntasan klasikal $75 \%$. Siklus II terjadi peningkatan rata-rata 86,78 dan ketuntasan klasikal $100 \%$. Respons siswa tergolong positif pada kedua siklus. Simpulan dari penelitian ini adalah penerapan model pembelajaran kooperatif tipe (STAD) melalui teka-teki silang dapat meningkatkan penguasaan huruf Hiragana siswa dengan respons yang positif.
\end{abstract}

Kata kunci: model pembelajaran kooperatif tipe STAD, media teka-teki silang, huruf Hiragana.

要旨

本研究の目的は学生でにおけるメディアクロスワードのSTAD協調学習モデルの応用によっ て行われた平仮名習得力と学生の反応を高めるためである。調査は2回の授業研究である。 調査協力者は、南クタ第一高等学校の言語クラスの2年生、28名である。調査方法は、観 察、テストとアンケートである。収集したデータは、定性的記述法により分析した。応用し たメディアクロスワードによる STAD協調学習モデルで、平仮名の習得力が何上したこと分 かった、つまり17,85\%の全体の達成率は、成績が50,53点の平均プレテストが得られたこと によって示された。サイクル にでは、平均プレテストの成績が78点であり、全体の達成率が 75\%であった。サイクルIで、平均プレテストの成績が 86,78 点、古典的完全性は100\% の増 加が見られた。学習者の反応について、1回で平均が43であり、2回での平均が45である。 平仮名の習得力を高めるのに応用したSTADによるメディアクロスワードの実施（応用）に よって学習者の反応が良いということが分かった。

キーワード : STAD協調学習モデル、メディアクロスワード、平仮名

\section{Pendahuluan}

Bahasa Jepang merupakan salah satu bahasa asing yang diminati di dunia, termasuk juga di Indonesia. Dalam mempelajari bahasa asing terdapat empat keterampilan yang terdapat dalam berbahasa yaitu mendengarkan, berbicara, membaca dan menulis. Hendaknya keempat aspek tersebut harus dikuasai dengan baik dalam pembelajaran bahasa asing. Dalam mempelajari bahasa asing khususnya bahasa Jepang memiliki 
kesulitan tersendiri karena dalam huruf bahasa Jepang memiliki karakteristik yang berbedabeda.

Huruf merupakan dasar yang harus dipelajari dan dikuasai oleh siswa dalam belajar bahasa Jepang seperti huruf Hiragana, Katakana, dan Kanji. Pembelajaran di sekolah huruf Hiragana merupakan huruf pertama yang dipelajari oleh siswa. Penggunaan huruf Hiragana akan digunakan selanjutnya pada huruf Katakana dan Kanji. Apabila siswa mampu menguasai huruf Hiragana dengan baik tentunya akan memudahkan siswa dalam mempelajari huruf Katakana dan Kanji. Tetapi, kenyataannya tidak semua siswa mampu menguasai huruf Hiragana dengan baik. Hal itu disebabkan penguasaan huruf Hiragana yang dialami oleh siswa, baik dari segi penulisan maupun bentuk dari huruf itu sendiri masih rendah.

Berdasarkan pada observasi awal yang telah dilakukan pada hari Rabu tanggal 24 Januari 2018 di kelas XI Bahasa diketahui bahwa di kelas tersebut siswa masih belum menguasai huruf Hiragana. Pemilihan kelas XI Bahasa untuk penelitian ini karena mempelajari bahasa Jepang khususnya huruf Hiragana merupakan salah satu unsur terpenting yang tidak dapat diabaikan dan wajib dikuasai oleh pembelajar jurusan bahasa. Menguasai huruf Hiragana akan sangat membantu siswa dalam mempelajari bahasa Jepang terutama dalam menulis kosakata dan membaca huruf, selain itu dengan menguasai huruf Hiragana siswa akan lebih mudah menguasai huruf lainnya yaitu Katakana dan Kanji pada jenjang kelas berikutnya. Berdasarkan hasil pengamatan yang dilakukan di SMA Negeri 1 Kuta Selatan pada kelas XI Bahasa, siswa ketika disuruh menulis dan membaca kata ataupun kalimat bahasa Jepang dalam huruf Hiragana mereka merasa kesulitan. Kesulitan yang dialami berupa mengingat bentuk huruf, kesulitan dalam membedakan huruf dan menulis huruf dengan baik.

Untuk mengatasi kesulitan yang dihadapi oleh siswa terlebih penggunaan model pembelajaran yang selama ini digunakan saat proses belajar mengajar di kelas kurang efektif karena tidak merangsang siswa menjadi aktif. Saat menemui kesulitan dalam pembelajaran, siswa masih saja enggan bertanya saat menghadapi kesulitan karena merasa malu. Sehingga diperlukan model pembelajaran lain yang tepat agar siswa aktif dan tidak malu untuk bertanya saat mengalami kesulitan dalam pembelajaran bahasa Jepang di kelas.

Dalam proses pembelajaran juga dibutuhkan adanya penerapan model pembelajaran, seperti model pembelajaran kooperatif yang lebih menekankan belajar dalam kelompok heterogen saling membantu satu sama lain. Hal ini sesuai dengan pendapat Suyatno (2009:51) bahwa model pembelajarn kooperatif adalah kegiatan belajar dengan berkelompok untuk bekerja sama saling membantu mengkonstruksi konsep, menyelesaikan persoalan, atau inkuiri. Berbicara masalah model pembelajaran, guru memiliki peran yang sangat penting dalam hal ini. Pemilihan model pembelajaran yang tepat akan memungkinkan ketercapaian tujuan pembelajaran secara maksimal. Dalam mengajar guru harus bisa memilih strategi, metode, dan teknik yang tepat dalam proses pembelajaran sehingga dapat memberikan peningkatan minat dan motivasi siswa.

Selain itu diperlukan juga media sebagai penunjang proses pembelajaran di kelas. Pemberian media yang menarik kepada siswa dapat mengatasi rasa jenuh siswa saat belajar bahasa Jepang. Karena itu penggunaan media teka-teki silang akan diterapkan di kelas XI Bahasa. Media teka-teki silang ini dapat melatih siswa untuk meningkatkan daya ingat terhadap huruf Hiragana. Latihan mengingat membantu siswa menggunakan pemikiran mereka untuk fokus dan menyimpan informasi. dengan sering berlatih mengulang Hiragana menggunakan media teka-teki silang, maka siswa dapat menguasai serta menjadi terbiasa dalam menulis atau mengingat huruf Hiragana, karena dengan menerapkan media teka-teki silang siswa dapat meningkatkan aktivitas dan hasil belajar peserta didik.

Penelitian dengan menggunakan model pembelajaraan kooperatif tipe Student Team Achievement Divisions (STAD) melalui permainan teka-teki silang yang dilakukan oleh Aditya (2014) menunjukkan peningkatan terhadap pemahaman kosakata bahasa Jepang pada siswa kelas XI UPW B SMK Negeri 1 Singaraja Tahun Ajaran 2013/2014. Hasil penelitian menunjukkan bahwa penerapan model pembelajaran kooperatif tipe STAD berbantuan teka-teki silang sudah dapat dikatakan berhasil karena telah terjadi peningkatan 
pada presentase ketuntasan tes, pada tes awal yaitu $23 \%$, post-test I menjadi $74 \%$, dan pada post-test II terjadi peningkatan sebesar $100 \%$.

Selain itu, penelitian dengan model pembelajaran kooperatif tipe STAD berbantuan media permaian puzzle juga pernah dilakukan oleh Ardita (2015) menunjukkan peningkatan terhadap penguasaan kosakata bahasa Jepang pada siswa kelas X3 SMA Karya Wisata Singaraja Tahun Ajaran 2014/2015. Hasil penelitian ini menunjukkan bahwa penerapan model pembelajaran kooperatif tipe Student Team Achievement Division (STAD) berbantuan media permainan puzzle sudah berhasil karena telah terjadi peningkatan pada presentase ketuntasan tes, pada tes awal yaitu $51,76 \%$, kemudian pada post-test I menjadi $85,54 \%$, dan pada post-test II terjadi peningkatan sebesar 95,30\%.

Maka dari itu, dengan penggunaan model pembelajaran kooperatif tipe Student Team Achievement Divisions (STAD) melalui media teka-teki silang diharapkan penguasaan huruf Hiragana siswa kelas XI Bahasa SMA Negeri 1 Kuta Selatan dapat meningkat. Siswa diharapkan mampu menguasai dan menggunakan huruf Hiragana dengan baik. Penguasaan huruf Hiragana siswa ketika sudah mulai ada perubahan menjadi lebih baik, maka kedepannya saat menjawab soal-soal yang berisikan huruf Hiragana mendapat nilai yang memuaskan. Selain itu, guru dalam pengajarannya menjadi lebih mudah menjelaskan dan mengajarkan bahasa Jepang kepada siswa karena penguasaan huruf Hiragana sudah mengalami peningkatan ke arah yang lebih baik.

Adapun rumusan masalah dari penelitian ini yaitu.

1. Apakah penerapan model pembelajaran kooperatif tipe STAD (Student Teams Achievement Division) melalui media teka-teki silang dapat meningkatkan penguasaan huruf Hiragana pada siswa kelas XI Bahasa SMA Negeri 1 Kuta Selatan Tahun Ajaran 2017-2018?

2. Bagaimana respons siswa kelas XI Bahasa SMA Negeri 1 Kuta Selatan Tahun Ajaran 2017/2018 terhadap penerapan model pembelajaran kooperatif tipe STAD (Student Teams Achievement Division) melalui media teka-teki silang untuk meningkatkan penguasaan huruf Hiragana?

\section{Metode}

Pada metode penelitian dilakukan enam langkah diantaranya, rancangan penelitian, lokasi penelitian, sumber data, metode dan instrumen pengumpulan data, metode dan teknis analisis data dan kriteria keberhasilan penelitian. Berikut penjabarannya.

Jenis penelitian ini adalah penelitian tindakan kelas. Penelitian tindakan kelas merupakan tindakan mengumpulkan, mengolah, menganalisis, dan menyimpulkan data untuk menentukan tingkat keberhasilan jenis tindakan yang dilaksanakan oleh guru dalam proses pembelajaran. Penelitian tindakan kelas (PTK) diawali dari adanya masalah yang dirasakan oleh guru dalam pembelajaran di kelas. Masalah tersebut kemudian dianalisis dan direfleksi untuk diketahui faktor-faktor penyebabnya, setelah jelas faktor penyebabnya, selanjutnya masalah tersebut dirumuskan kemudian dicari strategi atau metode untuk memecahkan masalah tersebut.

PTK merupakan proses pengkajian masalah pembelajaran di dalam kelas melalui refleksi diri dan upaya untuk memecahkannya dengan cara melakukan berbagai tindakan yang terencana dalam situasi nyata serta menganalisis setiap pengaruh dari tindakan tersebut (Sanjaya 2013:19). Alasan diadakannya penelitian tindakan kelas karena terdapat permasalahan tentang kurangnya penguasaan huruf Hiragana pada siswa XI Bahasa SMA Negeri 1 Kuta Selatan. Tujuan dari PTK ini adalah mengembangkan sebuah model pembelajaran kooperatif tipe STAD melalui media teka-teki silang untu membantu memecahkan permasalahan guru dan siswa yang menjadi kendala selama ini.

Penelitian ini dilaksanakan pada siswa kelas XI Bahasa SMA Negeri 1 Kuta Selatan yang berlokasi di Jalan Ketut Jetung Kutuh Kuta Selatan. Pemilihan tempat penelitian ini didasarkan pada hasil observasi yang dilakukan di kelas XI Bahasa di SMA Negeri 1 Kuta Selatan dengan mengamati proses pembelajaran bahasa Jepang. Pemahaman siswa akan huruf Hiragana masih rendah dan kurangnya penerapan model pembelajaran yang menarik minat siswa dalam mempelajari bahasa Jepang khususnya pada huruf Hiragana sehingga 
perlu dilaksanakan suatu tindakan agar siswa tidak terus-menerus mengalami kendala dalam mempelajari bahasa Jepang agar minat siswa tidak berkurang dalam mempelajari bahasa asing.

Sumber dalam penelitian ini adalah siswa kelas XI Bahasa SMA Negeri 1 Kuta Selatan. Jumlah siswa kelas XI Bahasa yaitu 28 orang yang terdiri dari 13 orang laki-laki dan 15 orang perempuan. Objek penelitian ini terdapat dua jenis, yang pertama mencangkup aktifitas siswa selama mengikuti pembelajaran menggunakan model pembelajaran kooperatif tipe STAD melalui media teka-teki silang. Sedangkan objek kedua yaitu mengcangkup peningkatan penguasaan huruf Hiragana pada siswa.

Untuk memperoleh data yang baik dan akurat dalam penelitian ini beberapa instrumen yang digunakan dalam penelitian ini, yaitu berupa kuesioner dan wawancara.

1. Observasi

Kanca (2010:140) observasi dalam PTK dipandang sebagai teknik yang paling tepat digunakan untuk mengumpulkan data, mengingat data yang diperlukan adalah data tentang proses pembelajaran, disamping data tentang hasil kegiatan pembelajaran. Pada penelitian ini menggunakan teknik observasi langsung yaitu mengamati langsung dalam kegiatan pembelajaran bahasa Jepang di kelas XI Bahasa SMA Negeri 1 Kuta Selatan tahun ajaran 2017/2018.

Selama pelaksanaan tindakan langsung dilakukan observasi terhadap aktivitas siswa dalam penerapan model pembelajaran kooperatif tipe STAD (Student Teams Achievement Divinions) melalui media teka-teki silang, adapun langkah-langkah observasi yang dilakukan sebagai berikut.

a. Mengobservasi responden keaktifan siswa selama proses pembelajaran.

b. Mengobservasi reaksi atau tindakan siswa selama pembelajaran.

2. Tes

Arikunto (2010) Tes merupakan alat atau prosedur yang digunakan untuk mengetahui atau mengukur sesuatu dalam suasana dengan cara dan aturan-aturan yang sudah ditentukan. Test digunakan untuk mengetahui kemampuan siswa dalam penguasaan huruf Hiragana. Test yang diberikan dari pretest dan posttest, dari hasil test tersebut akan dianalisis. Test ini berupa soal menyalin kehuruf Hiragana dengan 20 soal yang masing-masing diberikan pada siklus I yaitu pada Rabu, 9 Mei 2018. Pada siklus II yaitu pada Selasa, 22 Mei 2018.

3. Kuesioner

Sugiyono (2014) Kuesioner merupakan salah satu media yang digunakan untuk pengumpulan data penelitian. Kuesioner disebarkan kepada responden yaitu 28 siswa sebagai penelitian, mengandung pertanyaan-pertanyaan yang berkaitan dengan objek penelitian. Kuesioner disebarkan sebanyak dua kali pada siklus I dan siklus II.

Berdasarkan jenisnya, kuesioner yang digunakan pada penelitian ini adalah kuesioner tertutup yang dianalisis secara kuantitatif. Kuesioner tersebut diberikan kepada siswa setelah pelaksanaan pada setiap siklus. Hasil kuesioner akan dijadikan masukan dalam merancang tindakan berikutnya dan juga digunakan untuk mengetahui respons siswa terhadap penerapan model pembelajaran kooperatif tipe STAD (Student Teams Achievement Divinions) melalui permainan teka-teki silang.

Untuk menjawab permasalahan penelitian yang sudah ditetapkan maka data yang terkumpul harus dianalisis terlebih dahulu. Aspek yang ingin diketahui dalam penelitian ini adalah penerapan model pembelajaran kooperatif tipe STAD (Student Teams Achievement Division) melalui permainan teka-teki silang yang dapat meningkatkan penguasaan huruf Hiragana pada siswa kelas XI Bahasa di SMA Negeri 1 Kuta Selatan Tahun Ajaran 2017/2018.

Adapun analisis data yang dimaksud dalam penelitian ini adalah diantaranya hasil lembar observasi dan kuesioner. Hasil data tersebut berupa data kualitatif, analisis kualitatif sendiri digunakan untuk menganalisis data yang menunjukan proses interaksi yang terjadi selama pembelajaran berlangsung, dimana respons siswa terhadap proses pembelajaran huruf Hiragana dengan menggunakan model pembelajaran kooperatif tipe STAD (Student Teams Achievement Divinions) melalui permainan teka-teki silang. Sedangkan data 
kuantitatif diambil melalui hasil test yang diberikan untuk mengetahui sejauh mana tingkat kemampuan siswa dalam menguasai huruf Hiragana dan hasil kuesioner siswa selama menjalani siklus I dan siklus II.

Konsep dasar dari Kurikulum 2013 yaitu pengetahuan tidak dapat dipindahkan begitu saja dari guru ke peserta didik. Guru memberikan kemudahan untuk proses ini, dengan mengembangkan suasana belajar yang memberi kesempatan peserta didik untuk menemukan, menerapkan ide-ide mereka sendiri, menjadi sadar dan secara sadar menggunakan strategi mereka sendiri untuk belajar. (Permendikbud Nomor 81 A tahun 2013). Atas dasar tersebut dan kurikulum yang dipergunakan di kelas XI Bahasa di SMA Negeri 1 Kuta Selatan yaitu kurikulum 2013 maka yang dijadikan kriteria keberhasilan adalah KKM mata pelajaran bahasa Jepang di kelas XI Bahasa. Kriteria keberhasilan yang digunakan untuk huruf Hiragana siswa kelas XI Bahasa SMA Negeri 1 Kuta Selatan dengan menerapkan model pembelajaran kooperatif tipe STAD melalui media teka-teki silang adalah apabila $75 \%$ dari jumlah siswa memperoleh 75 ke atas.

\section{Hasil dan Pembahasan}

Berdasarkan pada rancangan di metode penelitian, penelitian ini diawali dengan pemberian tes awal (pretest). Tujuan dari pemberian tes awal ini adalah untuk mengetahui kemampuan awal dari siswa terhadap penguasaan huruf Hiragana. Selain itu untuk membuktikan bahwa penguasaan huruf Hiragana siswa kelas XI Bahasa di SMA Negeri 1 Kuta Selatan masih sangat kurang. Data ini diperoleh dengan melaksanakan pre-test penguasaan huruf Hiragana pada tanggal 25 April 2018 kepada semua siswa kelas XI Bahasa. Adapun dalam pelaksanaan pre-test ini memberikan 20 soal dengan 10 soal untuk mengubah kosakata kedalam huruf Hiragana dan 10 soal mengubah dari huruf Hiragana kedalam romaji, waktu yang diberikan kepada siswa untuk mengerjakan tes yaitu 45 menit atau satu jam pelajaran.

Sebanyak 21 orang siswa (75\%) yang mendapatkan nilai di bawah KKM. Sebanyak 1 orang siswa $(3,57 \%)$ yang mendapatkan nilai 90 , sebanyak 2 orang siswa $(7,14 \%)$ yang mendapatkan nilai 85 , sebanyak 2 orang siswa (7,14\%) yang mendapatkan nilai 80 , sebanyak 1 orang siswa $(3,57 \%)$ yang mendapatkan nilai 65 , sebanyak 1 orang siswa $(3,57 \%)$ yang mendapatkan nilai 60 , sebanyak 5 orang siswa $(17,85 \%)$ yang mendapatkan nilai 55 , sebanyak 1 orang siswa $(3,57 \%)$ yang mendapatkan nilai 50 , sebanyak 4 orang siswa $(14,28 \%)$ yang mendapatkan nilai 45 , sebanyak 2 orang siswa $(7,14 \%)$ yang mendapatkan nilai 40 , sebanyak 3 orang siswa $(10,71 \%)$ yang mendapatkan nilai 35 dan 6 orang siswa $(21,42 \%)$ yang mendapatkan nilai 30 . Nilai rata-rata yang didapatkan oleh siswa adalah 50,53.

\section{Siklus I}

Pelaksanaan tindakan siklus dilakukan pada hari Rabu tanggal 2 Mei 2018 di kelas XI Bahasa SMA Negeri 1 Kuta Selatan pada jam 7/8 dengan jumlah siswa 28 orang. Pelaksanaan siklus terdiri dari 2 sesi. Pada sesi pertama membahas materi mengenai まい にちの せいかつ. Pada pertemuan pertama, materi yang diberikan adalah huruf Hiragana あ、い、う、え、お、か、き、く、け、こ、さ、し、す、せ、そ、た、ち、つ、て、と、な 、に、ぬ、亦、の.

Pelaksanaan siklus I sesi kedua dilanjutkan pada hari Selasa tanggal 8 Mei 2018 pada jam 3-4. memberikan huruf Hiragana は、ひ、ふ、へ、ほ、ま、み、む、め、も、や 、ゆ、よ、ら、り、る、れ、ろ、わ、を dan ん. Serta penggunan huruf Hiragana yang menggunakan tanda (...") dan (.. ).

Setelah itu, siswa diberikan kosakata yang masih dengan tema kehidupan sehari-hari yaitu dengan materi ひまなとき. Setelah tindakan pada siklus satu yang terdiri dari dua sesi telah dilaksanakan, diperoleh hasil post-test yang diberikan kepada siswa untuk mengukur kemampuan siswa dalam penguasaan huruf Hiragana dengan model pembelajaran kooperatif tipe STAD melalui teka-teki silang diterapkan dalam pembelajaran. Tes tersebut dilaksanakan pada hari Rabu tanggal 9 Mei 2018 di kelas XI Bahasa. Pelaksanaan post-test, sama halnya pada saat pelaksanaan pre-test. Adapun hasil post-test penguasaan huruf Hiragana siswa adalah sebagai berikut 21 (75\%) orang siswa 
mendapatkan nilai tuntas sesuai dengan nilai kriteria ketuntasan minimal yaitu 70 dan mengalami peningkatan dari hasil pre-test. Sedangkan siswa yang tidak tuntas 7 (25\%) orang siswa. dari tabel diatas dapat dikatakan bahwa terdapat 1 orang siswa $(3,57 \%)$ yang mendapatkan nilai 100, 3 orang siswa (10,71\%) yang mendapatkan nilai 95, 3 orang siswa $(10,71 \%)$ yang mendapatkan nilai 89,4 orang siswa $(14,28 \%)$ yang mendapatkan nilai 83,7 orang siswa (25\%) yang mendapatkan 79,3 orang siswa siswa $(10,71 \%)$ yang mendapatkan nilai 74,4 orang siswa $(14,28 \%)$ yang mendapatkan nilai 63,2 orang siswa $(7,14 \%)$ yang mendapatkan nilai 58 dan 1 orang siswa $(3,57 \%)$ yang mendapatkan nilai 53 . Berdasarkan pada nilai kriteria ketuntasan minimal (KKM) sebesar 70, maka siswa yang lulus dalam posttest I adalah sebanyak 21 orang dan siswa yang tidak lulus dalam post-test I adalah sebanyak 4 orang. Nilai rata-rata dari seluruh siswa yang diperoleh pada post-test I adalah 78.

Kuesioner diberikan kepada siswa untuk mengetahui bagaimana respon siswa terhadap penerapan model pembelajaran STAD melalui teka-teki silang untuk meningkatkan penguasaan huruf Hiragana. Kuesioner diberikan kepada siswa pada hari Rabu tanggal 6 Mei 2018 di kelas XI Bahasa SMA Negeri 1 Kuta Selatan. Angket ini diberikan setelah siswa selesai menjawab tes (post-test). Diketahui jumlah kuesioner respons dari siswa terhadap penerapan model pembelajaran kooperatif tipe STAD melalui teka-teki silang adalah 1194 dengan rata-rata 43. Berdasarkan hasil perhitungan respons siswa kelas XI Bahasa SMA Negeri 1 Kuta Selatan tahun ajaran 2017/2018 terhadap penerapan model pembelajaran kooperatif tipe STAD melalui teka-teki silang, respons siswa berada pada penggolongan "Positif".

\section{Siklus II}

Pada pelaksanaan tindakan siklus II dilaksanakan sesuai dengan rencana tindakan sebelumnya. Setiap siklus terdiri dari tiga kali pertemuan, masing-masing terdiri dari dua kali pertemuan untuk melakukan proses pembelajaran dengan materi yang berbeda dan, dan satu kali pertemuan untuk mengadakan evaluasi seperti memberikan post-test, dan memberikan kuesioner pada siswa.

Pada pertemuan pertama siklus II dilaksanakan pada Selasa 15 Mei jam ke 3-4 dengan menerapkan model pembelajaran kooperatif tipe STAD melalui media teka-teki silang di kelas XI Bahasa SMA Negeri 1 Kuta Selatan. Materi yang akan diajarkan pada pertemuan pertama siklus II mengenai huruf Hiragana が sampai ぽ. Selain materi tersebut akan diajarkan juga terkait kosakata pada tema berbelanja かいもの. Kendala yang dihadapi pada pertemuan pertama siklus II yaitu masih ada siswa yang bercanda saat proses pembelajaran.

Pada pertemuan kedua siklus II dilaksanakan pada Rabu, 16 Mei 2018 jam ke 7-8 dengan materi baru yaitu huruf Hiragana きゃ sampaiぴょ dan tema baru yaitu keadaan kota (まち). Pada kegiatan inti, siswa diberikan huruf Hiragana きゃ sampaiぴょ serta memberikan kosakata baru mengenai materi yang akan dipelajari.

Setelah melakukan pelaksanaan tindakan siklus II dengan model pembelajaran kooperatif tipe STAD melalui media teka-teki silang, kemudian untuk mengetahui penguasaan siswa dalam huruf Hiragana, maka tes penguasaan huruf Hiragana diberikan. Tes penguasaan huruf Hiragana ini dilaksanakan pada Selasa, 22 Mei 2018 di kelas XI Bahasa. Hasil post-test penguasaan huruf Hiragana diatas, semua siswa mendapatkan nilai tuntas sesuai dengan nilai kriteria ketuntasan minimal yaitu 70 dan mengalami peningkatan dari hasil post-test siklus I. Setelah nilai tersebut dikategorikan, diketahui 22 orang (79\%) termasuk kategori sangat baik, 6 orang (21\%) termasuk kategori baik, sedangkan tidak ada siswa masuk dalam kategori cukup, kurang dan sangat kurang. Pada post-test siklus II adalah 100 yang didapatkan oleh 2 orang siswa sedangkan nilai terendah pada siklus II adalah 75 yang didapatkan oleh 1 orang siswa. Seluruh siswa memperoleh nilai di atas KKM sebanyak $100 \%$.

Diketahui bahwa terjadi peningkatan nilai dalam penguasaan huruf Hiragana siswa setelah diterapkannya model pembelajaran STAD melalui media teka-teki silang. Setiap siswa mengalami peningkatan nilai, seluruh siswa mendapatkan nilai sesuai dengan KKM 
meningkat menjadi 28 orang dan rata-rata nilai siswa yang diperoleh siswa dari 50,53 yaitu nilai pretest, 74,10 yaitu nilai post-test I dan 86,78 nilai pada post-test II. Sedangkan nilai ketuntasan klasikal siklus II meningkat menjadi 100\%. Untuk lebih jelasnya perbandingan nilai pre-test dengan post-test I dan post-test II ditampilkan dalam bentuk gambar berikut.

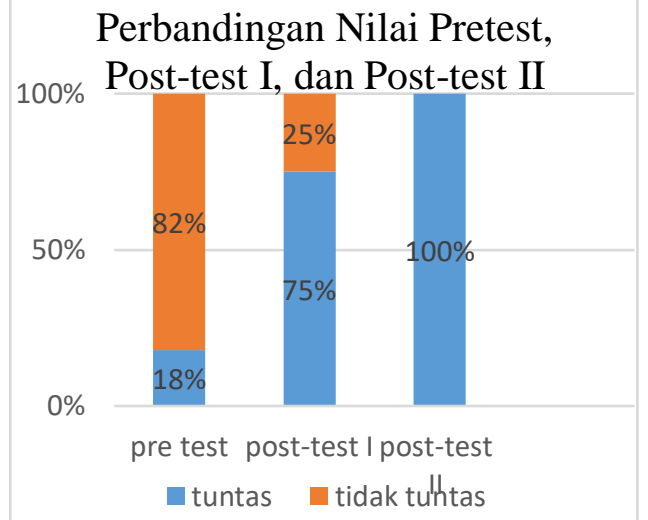

Terlihat jelas peningkatan siswa yang mendapatkan nilai sesuai dengan KKM setelah diterapkannya model pembelajaran kooperatif tipe STAD melalui media teka-teki silang dalam penguasaan huruf Hiragana.

Dari data yang diperoleh secara keseluruhan, penerapan model pembelajaran kooperatif tipe STAD melalui media teka-teki silang dalam penguasaan huruf Hiragana siswa. Nilai ketuntasan klasikal siswa pada siklus I sebesar $75 \%$, dan pada siklus II terjadi peningkatan yaitu $100 \%$ hal ini sudah dianggap memenuhi kriteria keberhasilan siswa mendapatkan nilai sesuai dengan KKM. Jadi dapat disimpulkan penerapan model pembelajaran STAD melalui media teka-teki silang memengaruhi hasil belajar siswa. Hal tersebut terlihat dari perbandingan peningkatan nilai yang diperoleh siswa dalam penguasaan huruf Hiragana.

Diketahui jumlah kuesioner respons siswa terhadap penggunaan model pembelajaran kooperatif tipe STAD melalui teka-teki silang adalah 1218 dengan rata-rata 45. Dari hasil perhitungan yang telah dilakukan, diketahui hasil respons siswa kelas XI Bahasa SMA Negeri 1 Kuta Selatan tergolong "Positif" dengan hasil 39,5<45<46,5. Dilihat dari kuesioner tertutup dapat disimpulkan bahwa siswa kelas XI Bahasa merespons positif penerapan model pembelajaran kooperatif tipe STAD melalui teka-teki silang untuk meningkatkan penguasaan huruf Hiragana.

\section{PEMBAHASAN}

Berdasarkan hasil temuan yang dilakukan di kelas XI Bahasa SMA Negeri 1 Kuta Selatan pada pelajaran bahasa Jepang dengan menggunakan model pembelajaran kooperatif tipe STAD melalui media teka-teki silang untuk meningkatkan penguasaan huruf Hiragana siswa. Pada hasil belajar siswa menunjukkan adannya peningkatan dari siklus I sampai siklus II dengan diterapkannya model pembelajaran kooperatif tipe STAD melalui media teka-teki silang. Tercapainya keberhasilan dalam menerapkan model pembelajaran kooperatif tipe STAD tidak terlepas dari persiapan yang dilakukan sebelum mengajar seperti menyusun rancangan pembelajaran yang sesuai dengan kurikulum yang diterapkan di SMA Negeri 1 Kuta Selatan yaitu Kurikulum 2013, mengikuti langkah-langkah model pembelajaran kooperatif tipe STAD, serta menyiapkan media teka-teki silang sebagai sarana pendukung untuk mengajar.

Dengan diterapkannya model pembelajaran kooperatif tipe STAD melalui media tekateki silang, siswa diharapkan tidak merasa jenuh ketika menerima pembelajaran di kelas. Selain itu, untuk memenuhi kebutuhan siswa agar tercapai tujuan pembelajaran yang baik maka diterapkan suatu model pembelajaran yang disesuaikan dengan karakteristik siswa. Sebelum model pembelajaran kooperatif tipe STAD melalui media teka-teki silang diterapkan di kelas XI Bahasa dilakukan observasi awal untuk mengetahui permasalahan yang di hadapi oleh siswa. adapun yang menjadi permasalahan siswa yaitu siswa kurang dalam 
penguasaan huruf Hiragana, kurang dalam membaca kosakata yang menggunakan huruf Hiragana, serta tidak ada rasa percaya diri ketika menjawab soal karena kurangnya motivasi dan perhatian yang khusus diberikan pada siswa.

Penerapan model pembelajaran kooperatif tipe STAD melalui media teka-teki silang dapat membantu siswa dalam penguasaan huruf Hiragana. Menggunakan model pembelajaran kooperatif tipe STAD berpusat pada siswa. Peran guru dalam pembelajaran ini hanya mengarahkan siswa agar tidak ada kendala yang menghambat siswa untuk belajar.

Berdasarkan hasil belajar siswa yang diperoleh dalam pelaksanaan penelitian dengan menggunakan model kooperatif tipe STAD melalui media teka-teki silang untuk meningkatkan penguasaan huruf Hiragana siswa kelas XI Bahasa SMA Negeri 1 Kuta Selatan sudah memenuhi kriteria keberhasilan pada KKM. Pada siklus I diperoleh ketuntasan klasikal sebesar $75 \%$ sedangkan pada siklus II mengalami peningkatan ketuntasan klasikal menjadi 100\%.

Setelah pelaksanaan pertemuan disetiap siklus dilaksanakan, dilanjutkan dengan disebarkannya kuesioner untuk mengetahui respons siswa. kuesioner diberikan kepada seluruh siswa kelas XI Bahasa dengan jumlah 28 orang. Setiap kuesinoer terdiri dari 10 soal pertanyaan dengan kuesioner tertutup. Rata-rata yang diperoleh dari kuesioner tertutup siklus I adalah 43, sedangkan rata-rata kuesioner siklus II adalah 45. Dari hasil kuesioner tersebut dapat digolongkan siswa merespons penerapan model pembelajaran kooperatif tipe STAD melalui media teka-teki silang dengan positif.

Jadi dapat disimpulkan bahwa penerapan model pembelajaran kooperatif tipe STAD melalui media teka-teki silang mampu meningkatkan penguasaan huruf Hiragana siswa kelas XI Bahasa SMA Negeri 1 Kuta Selatan tahun ajaran 2017/2018.

\section{Simpulan dan Saran}

Simpulan yang dapat ditarik berdasarkan analisis terhadap hasil PTK pada siswa kelas XI Bahasa SMA Negeri 1 Kuta Selatan dengan menggunakan model pembelajaran kooperatif tipe STAD melalui teka-teki silang yaitu,

1. Penerapan model pembelajaran kooperatif tipe STAD melalui media teka-teki silang dapat meningkatkan penguasaan huruf Hiragana siswa kelas XI Bahasa di SMA Negeri 1 Kuta Selatan. Peningkatan ini terbukti pada siklus I yang diperoleh rata-rata nilai siswa adalah 78 dan ketuntasan klasikal mencapai $75 \%$. Pada siklus II terjadi peningkatan drastis dari hasil post-test II dengan rata-rata 86,78 dan ketuntasan klasikal $100 \%$. Dengan menggunakan hasil belajar model pembelajaran kooperatif tipe STAD melalui media teka-teki silang, ratarata nilai siswa meningkat dari siklus I ke siklus II. Rata-rata siklus II sudah mencapai kriteria ketuntasan yang ditentukan dalam penelitian ini yaitu tuntas apabila $75 \%$ siswa memenuhi syarat KKM.

2. Respons siswa kelas XI Bahasa di SMA Negeri 1 Kuta Selatan terhadap penerapan model model pembelajaran kooperatif tipe STAD melalui media teka-teki silang pada siklus I untuk meningkatkan penguasaan huruf Hiragana tergolong positif dengan rata-rata skor 43 sedangkan jumlah kuesioner siswa pada siklus II juga tergolong positif dengan rata-rata 45.

Saran yang dapat disampaikan dari penelitian terdapat dua saran diantaranya, (1)

Bagi guru ,penelitian ini diharapkan dapat menerapkan model pembelajaran kooperatif tipe STAD melalui media teka-teki yang dapat menarik perhatian siswa saat menerima pembelajaran bahasa Jepang.

(2) Bagi penelitian lain, hasil penelitian ini dapat sebagai acuan bagi peneliti lainnya apabila hendak melakukan penelitian pada bidang bahasa Jepang ataupun lainnya. Namun perlu untuk melihat hambatan-hambatan yang lebih dapat disempurnakan kembali dengan hasil penelitian ini dapat digunakan untk menambah wawasan.

\section{Daftar Pustaka}

Aditya, Dewa Gede Agung. 2014. "Penerapan Model Pembelajaran Kooperatif Tipe Student Teams Achievement Division (STAD) Melalui Permainan Teka-teki Silang untuk Meningkatkan Pemahaman Kosakata Bahasa Jepang pada Siswa Kelas XI UPW B 
SMK Negeri 1 Singaraja Tahun Ajaran 2013/2014". Singaraja: Universitas Pendidikan Ganesha.

Ardita, I Nyoman Agus. 2015. "Penerapan Model Pembelajaran Kooperatif Tipe STAD (Student Teams Achievement Division) Berbantuan Media Permainan Puzzle untuk Meningkatkan Penguasaan Kosakata Bahasa Jepang pada Siswa Kelas X3 SMA Karya Wisata Singaraja Tahun Ajaran 2014/2015". Singaraja: Universitas Pendidikan Ganesha.

Arikunto, Suharsimi. 2005. Manajemen Penelitian. Jakarta: PT Rineka Cipta.

Huda, Miftahul. 2013. Model-model Pengajaran \& Pembelajaran. Yogyakarta: Pustaka Pelajar.

Kanca, I Nyoman. 2010. Metode Penelitian Pengajaran. Singaraja: Universitas Pendidikan Ganesha.

Milliande. 2011. "Teka-teki Silang". Tersedia pada http://columbia. Thefreedictionary.com/crossword+puzzle (Diakses 10 April 2018).

Sanjaya, Wina. 2013. Penelitian Pendidikan. Jakarta: Kencana Perdana Media Group.

Sugiono. 2014. Metode Pendidikan (Pendekatan kuantitatif, kualitatif dan R\&D). Bandung: Alfabeta.

Suyatno. 2009. Menjelajah Pembelajaran Inovatif. Sidoarjo: Masmedia Buana Pustaka. 